\title{
11. GEOCHEMICAL WELL LOGS AND THE DETERMINATION OF INTEGRATED CHEMICAL FLUXES IN HOLE 504B, EASTERN EQUATORIAL PACIFIC ${ }^{1}$
}

\author{
Roger N. Anderson, ${ }^{2}$ Jeffrey C. Alt, ${ }^{3}$ and John Malpas ${ }^{4}$
}

\begin{abstract}
Geochemical well logs were used to measure the dry weight percent oxide abundances of $\mathrm{Si}, \mathrm{Al}, \mathrm{Ca}, \mathrm{Mg}, \mathrm{Fe}, \mathrm{Ti}$, and $\mathrm{K}$ and the elemental abundances of $\mathrm{Gd}, \mathrm{S}$, Th, and $\mathrm{U}$ at $0.15-\mathrm{m}$ intervals throughout the basement section of Hole 504B. These geochemical data are used to estimate the integrated chemical exchange resulting from hydrothermal alteration of the oceanic crust that has occurred over the last 5.9 Ma. A large increase in $\mathrm{Si}$ in the transition zone between pillows and dikes (Layers 2B and 2C) indicates that mixing of hot, upwelling hydrothermal fluids with cold, downwelling seawater occurred in the past at a permeability discontinuity at this level in the crust, even though the low-to-high permeability boundary in Hole 504B is now $500 \mathrm{~m}$ shallower (at the Layer $2 \mathrm{~A} / 2 \mathrm{~B}$ boundary). The observations of extensive $\mathrm{Ca}$ loss and $\mathrm{Mg}$ gain agree with chemical exchanges recorded in the laboratory in experiments on the reactions that occur between basalt and seawater at high temperatures. The $\mathrm{K}$ budget requires significant addition to Layer $2 \mathrm{~A}$ from both high-temperature depletion in Layers $2 \mathrm{~B}$ and $2 \mathrm{C}$ and low-temperature alteration by seawater. Integrated water/ rock ratios are derived for the mass of seawater required to add enriched elements and for the mass of hydrothermal fluid required to remove depleted elements in the crust at Hole 504B.
\end{abstract}

\section{INTRODUCTION}

Chemical reactions within submarine hydrothermal systems result in significant fluxes of elements into, and out of, the oceanic crust (e.g., Edmond et al., 1979). A volume of seawater equivalent to that of the entire oceans is thought to circulate through the ridge axes in approximately $7 \mathrm{Ma}$ (Sleep and Wolery, 1976). Concomitant chemical exchange with basalts not only alters the crust, but affects the composition of the oceans as well. For the mass budgets of many elements in seawater, hydrothermal exchange is as important as river input to the maintenance of a stable composition for the ocean over geologic time (e.g., Thompson, 1983).

Hot $\left(\sim 350^{\circ} \mathrm{C}\right)$, superheated, hydrothermal fluids exit the ridge axis at "black smokers," providing us with a view of active metallogenesis as metal sulfides, derived from reactions between seawater and basalts, are deposited directly onto the seafloor (e.g., Ballard and Francheteau, 1983). Helium and methane gases that escape with the hydrothermal fluids provide chemical tracers with which to map the deep circulation patterns of the oceans (Lupton and Craig, 1983). On the flanks of mid-ocean ridges, cold-water circulation continues the chemical exchange between the oceans and the crust for several tens of million years (c.f., Anderson and Hobart, 1976; Anderson et al., 1977). Moreover, the interaction of seawater with the oceanic crust produces secondary minerals that, when subducted, release fluids into the overlying mantle, affecting volcanism above downgoing plates (e.g., Anderson et al., 1980).

Chemical fluxes between seawater and the oceanic crust have been calculated for many elements based upon the compositions of fluid samples taken directly from effluents. Hydrothermal vent fluids, sampled at several locations along the axial rifts,

\footnotetext{
${ }^{1}$ Becker, K., Sakai, H., et al., 1989. Proc. ODP, Sci. Results, 111: College Station, TX (Ocean Drilling Program).

2 Borehole Research Group, Lamont-Doherty Geological Observatory, Columbia University, Palisades, NY 10964.

3 Department of Earth and Planetary Sciences, Washington University, St. Louis, MO 63130.

${ }^{4}$ Earth Sciences Department, Memorial University, St. John's, Newfoundland, A1B 3 X5 Canada.
}

provide the most accurate estimates to date (e.g., Edmond et al., 1979; Von Damm et al., 1983; Hekenian et al., 1983; Bowers and Edmond, in press). Despite continued exploration of midocean ridges and discoveries of additional high-temperature axial hydrothermal vents, problems remain with quantification of chemical fluxes in seafloor hydrothermal systems. For example, Morton and Sleep (1983) estimate that only about one-sixth of the convective heat loss from young oceanic crust occurs in high-temperature, axial circulation systems, whereas the remainder occurs during lower temperature convection that occurs off axis. Low-temperature, off-axis hydrothermal fluids have been sampled from pore waters of "hydrothermal mounds" at the Galapagos Spreading Center (Bender, 1983) and the Mariana Back-Arc Basin (e.g., Leinen et al., 1988), but only a primitive understanding of the chemical fluxes from these ridge flank systems presently exists. Analyses of another source of direct sampling, sediment pore fluids, often indicate that basalt-seawater exchange has continued far off axis, but again insufficient information is available from these data to place constraints upon the overall chemical mass balance (McDuff and Edmond, 1982; Mottl et al., 1983, 1985).

An alternative approach to determination of the chemical exchange between seawater and the oceanic crust is to measure changes in altered rocks from the seafloor and to estimate the distribution of the various alteration types (Thompson, 1983; Alt et al., 1986). This method has an advantage over direct fluid sampling in that the rocks integrate the mineralogical and chemical effects of alteration processes that have affected the rocks throughout their residence time on the seafloor. However, the problem remains of extrapolation of the processes observed in dredged rocks to those occurring in the subsurface.

Exposures of ophiolites on land allow complete sections of the oceanic crust to be collected. However, conclusions from analyses of ophiolites are complicated by the often-occurring overprint of metamorphism that accompanied emplacement and by variations in tectonic setting between different exposures (e.g., Honnorez et al., 1985).

Additional information about the variability and evolution of the chemical fluxes between oceanic crust and seawater can be gained from samples and measurements from drill holes within the oceanic crust (e.g., Anderson et al., 1985a; Alt et al., 
1986). Hole 504B was drilled on 5.9-Ma crust on the south flank of the Costa Rica Rift in the eastern equatorial Pacific Ocean during Deep Sea Drilling Project (DSDP) Legs 69, 70, 83, and 92 and Ocean Drilling Program Leg 111 (Becker, Sakai, et al., 1988). At $>1500 \mathrm{~m}$ below seafloor (mbsf), it is the deepest penetration yet into the oceanic crust (Fig. 1). As such, Hole 504B provides the first reference section of oceanic lithosphere for comparison to geochemical mass-balance models based upon surface sampling of fluids, rock, and ophiolites. However, interpretations based upon analyses of core suffer from the poor recovery in Hole 504B (less than 20\% of the section, and less than $15 \%$ of the deepest rock section). Consequently, great emphasis has been placed during DSDP and ODP upon the recording of in-situ geophysical logs to locate the recovered basalts within their proper geological framework and to interpret structure, lithology, and alteration history (e.g., Anderson et al., 1985a). In this chapter, we report the measurements from a new downhole measurement technology, geochemical logging, that allows us to estimate the integrated chemical exchange between the oceanic crust and seawater over the complete rock column in Hole $504 \mathrm{~B}$.

\section{STRUCTURAL SETTING}

The geophysical logging suite run in Hole 504B measured three distinct stratigraphic layers within the upper kilometer of basement (Newmark et al., 1985): (1) an upper 150-m-thick section of pillow and flow basalts with very low seismic velocity and resistivity (Layer 2A), (2) a middle layer of pillow basalts and flows with increasing velocity and slightly higher resistivity
(Layer 2B), and (3) a deep zone of basaltic dikes of high velocity and resistivity (Layer 2C) (Fig. 1). In parallel, three stratigraphic zones of alteration were defined based upon the occurrences of secondary minerals in cores from Hole 504B (Alt et al., 1986): (1) the upper $300 \mathrm{~m}$ of the pillow section was affected by lowtemperature (approximately $0^{\circ} \mathrm{C}$ ), oxidizing seafloor weathering, (2) the lower half of the pillow section (Layer 2B) was altered by low-temperature $\left(<100^{\circ} \mathrm{C}\right)$, reducing alteration, and (3) the dike section (Layer $2 \mathrm{C}$ ) was affected by greenschist hydrothermal metamorphism $\left(>250^{\circ} \mathrm{C}\right)$. Hot hydrothermal fluids upwelled through the dikes, mixed with cooler seawater circulating in the overlying pillow section, and deposited quartz and metal-rich sulfides into a stockwork mineralization zone near the lithologic transition from pillows to dikes (Honnorez et al., 1985). This stockwork was probably deposited at the ridge axis as part of a high-temperature, axial hydrothermal system that was active long before sealing of the crust by sediment deposition (which occurred approximately 1 m.y.B.P.; Hobart et al., 1985).

In spite of this complex alteration history, it is not difficult to find examples in the recovered core samples of horizons where a considerable amount of primary material still exists, including well-preserved chill margins of dikes. These rocks can be identified by thin-section observation, and their chemistry has been taken as most representative of the primary composition of the basalts at Hole 504B. The chemistry of the freshest basalts from Hole 504B is remarkably uniform throughout the well, making the determination of chemical fluxes much simpler than at other sites, where the basaltic chemistry might have var-

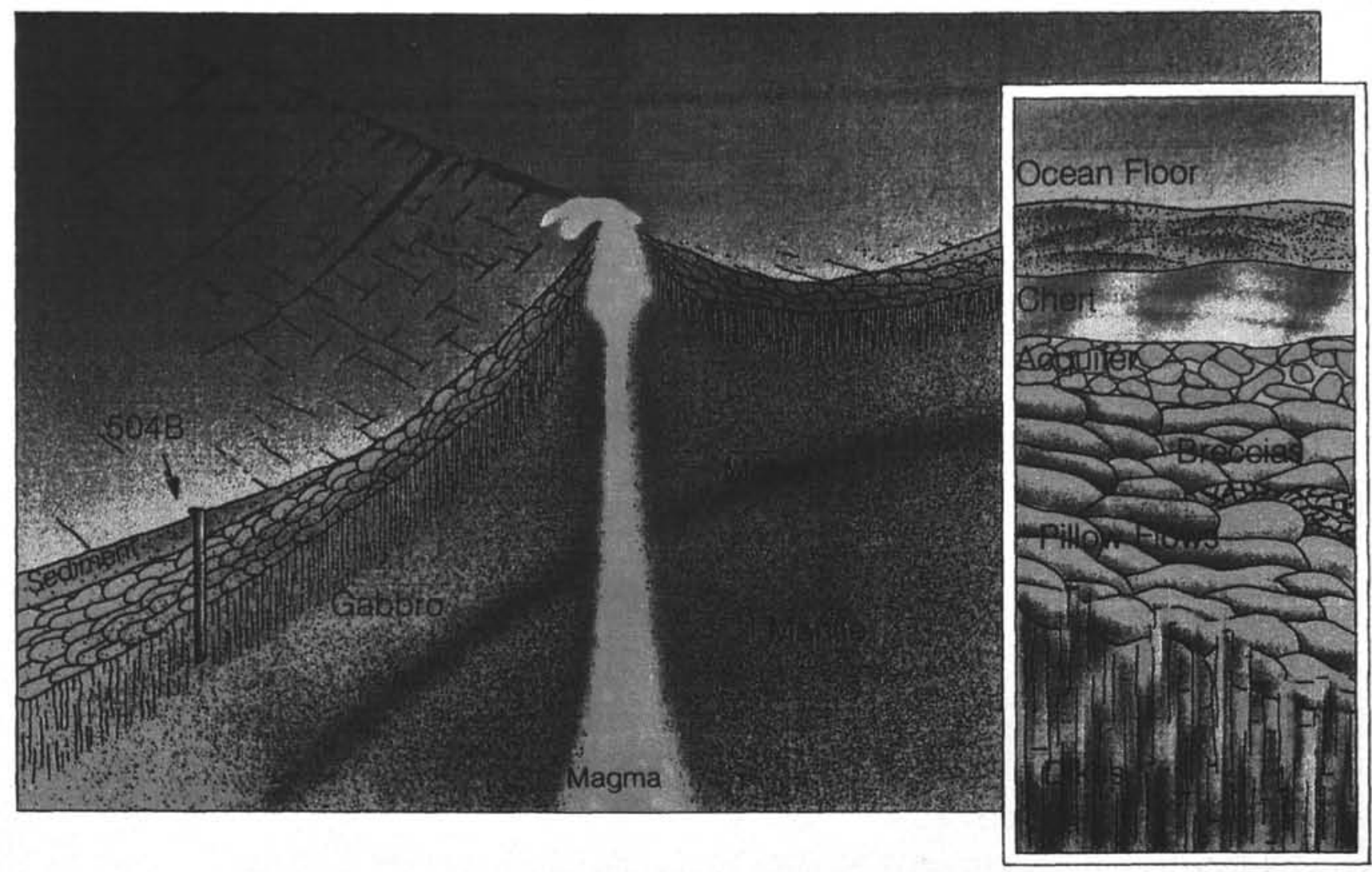

Figure 1. Schematic representation of the structure of the oceanic crust at Hole 504B in the eastern equatorial Pacific Ocean south of the Costa Rica Rift on the Nazca plate (from Anderson et al., 1988b). 
ied considerably with depth (such as at Hole 395A on the MidAtlantic Ridge).

The proper deciphering of chemical exchange between the ocean and the crust requires a complete view of the present composition of the section. That determined from only the $20 \%$ recovered by core is clearly not sufficient. In the following we describe the variation in chemistry of the basement section penetrated at Hole 504B by utilizing a sophisticated, high-technology, nuclear logging tool to activate the formation and measure the in-situ chemical composition of the rock at $0.15-\mathrm{m}$ intervals throughout the basement section.

\section{GEOCHEMICAL LOG ANALYSIS TECHNIQUES}

Geochemical well logging, developed by Schlumberger Well Services for use in sedimentary basins by the oil industry, is beginning to be used for science in drill holes through igneous and metamorphic rocks (Anderson et al., 1988a, 1988b, 1989). The geochemical logging tool measures the relative concentrations of 11 major and minor elements in situ. In turn, elemental and mineralogical abundances are derived, continuously, throughout the well. As shown by Anderson et al. (1988a, 1988b, 1989) the precision of geochemical log measurements within a well is excellent, although the accuracy is considerably poorer than that of analyses made on core samples in the laboratory, as might be expected.

The geochemical logging tool carries four measurement devices into the borehole (Fig. 2):

1. A Nal crystal, natural gamma-ray spectral analyzer detects the energy levels of naturally emitted gamma rays from the formation. The weight percent of potassium $(\mathrm{K})$ and abundances of thorium (Th) and uranium (U), in parts per million, are determined.

2. A californium neutron source, Nal scintillation detector activates aluminum atoms in the formation and records the emitted gamma rays. The weight percent of aluminum (Al) in the rock is subsequently calculated.

3. A pulsed neutron, capture gamma-ray spectrometer measures the abundances of silicon ( $\mathrm{Si})$, calcium $(\mathrm{Ca})$, iron $(\mathrm{Fe})$, sulfur (S), and titanium (Ti), as well as the trace abundance of the heavy rare earth element (HREE) gadolinium (Gd). Hydrogen $(\mathrm{H})$ and chlorine $(\mathrm{Cl})$ contents of the wellbore fluid and formation are also measured.

4. The photoelectric capture cross-section of the formation using a cesium source of gamma rays is combined with the preceding analyses to estimate the total concentration of magnesium $(\mathrm{Mg})$ plus sodium $(\mathrm{Na})$ in the rock by difference.

The gamma-ray spectroscopy measurements made by the geochemical logging tool detect a fraction of the total spectrum that is linearly proportional to the concentration of each element within the volume of the measurement (approximately $1 \mathrm{~m}^{3}$ ). Thus, the relative yields from the measured elements are renormalized to elemental oxides that are summed to $100 \%$ at each sampling depth interval (Hertzog et al., 1987). Because the elements measured by either capture activation or natural spectroscopy make up almost all of the significant oxides comprising rock, the calculations should be reliable in almost any geological formation (Hertzog et al., 1987; Anderson et al., 1988a).

In sediments, Schlumberger has demonstrated that geochemical logs yield measurements that can be converted to dry weight percent elemental oxides with accuracies of $5 \%$ to $20 \%$ (Hertzog et al., 1987). The precision of the elemental yields has been tested by up to 10 separate recordings within a well, with individual elemental abundances reproducible to better than $5 \%$. Anderson et al. (1988a, 1988b, 1989) showed the geochemical log measurements in basalts, granites, and metamorphic rocks are

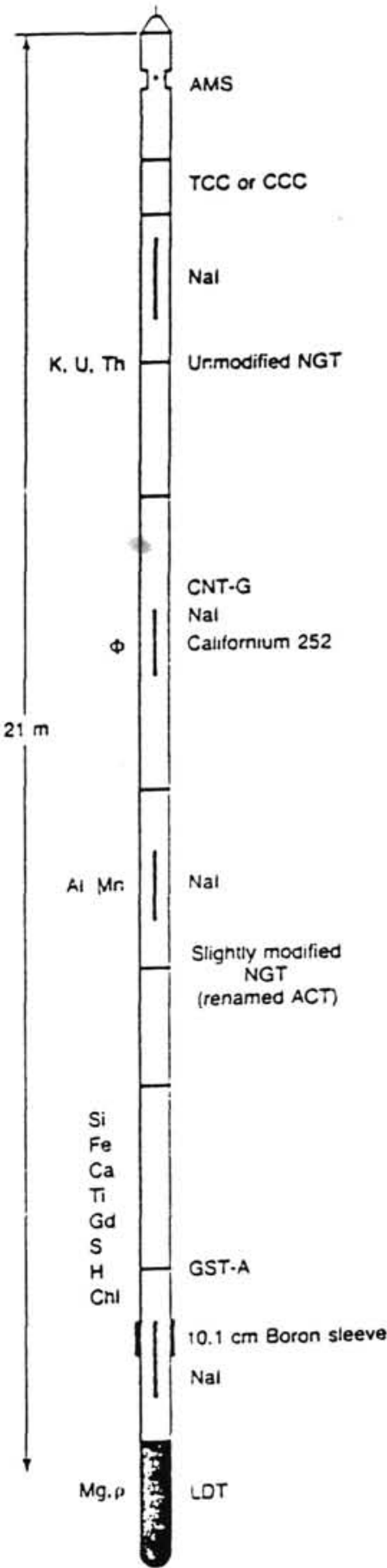

Figure 2. Configuration of the Schlumberger geochemical logging tool used in this study. At the top are the AMS (auxiliary measurement sonde), which determines temperature and cable tension), and the TCC or CCC (both of which telemeter digital information to the surface much like a complex telephone modem). K, $\mathrm{U}$, and Th are measured by the NGT (natural gamma-ray spectrometer). The CNT-G (compensated neutron tool) measures porosity and activates $\mathrm{Al}$ with a ${ }^{252} \mathrm{Ca}$ source. The ACT (aluminum clay tool) follows to measure $\mathrm{Al}$ concentration. The GST (gamma-ray spectrometer tool) uses a nuclear accelerator as a source for controlled bursts of neutrons, and then collects emitted gamma rays with a scintillation detector for the determination of the concentrations of $\mathrm{Si}, \mathrm{Fe}, \mathrm{Ca}, \mathrm{Ti}, \mathrm{Gd}, \mathrm{S}, \mathrm{H}$, and $\mathrm{Cl}$. An LDT (lithodensity tool) follows in the Ocean Drilling Program configuration. The LDT can be lowered separately to measure density and photoelectric capture cross-section using a cesium source. $\mathrm{Mg}(\mathrm{Mg}+\mathrm{Na})$ is calculated as a residual abundance from the combination of the total abundances of all other elements measured by the preceding. 
somewhat less accurate $(10 \%$ to $30 \%)$, although the precision remains excellent.

In spite of the poorer accuracy relative to laboratory analyses, geochemical well logs should add greatly to the geological reconnaissance capabilities within a drill hole because the logs provide analyses that are fast and relatively complete. As opposed to the many months required for laboratory analyses of the partial sections of a borehole that are recovered during most coring operations, continuous records of relative elemental yields are derived in real time while logging, and weight percentages of the major elemental oxide and trace element abundances are available within days. It is likely that geochemical well logging will become one of the most important scientific tools for the determination not only of lithology, but of stratigraphy, structure, source character, and degree of alteration in igneous and metamorphic, as well as sedimentary, rocks. In order to develop the methodology for interpretation of such geochemical well logs, we determine in the following the integrated chemical fluxes that resulted from metamorphism of basalts in Hole 504B.

\section{ELEMENTAL ABUNDANCES}

The geochemical logs allow us to quantitatively determine the chemical variability in Hole 504B, including the $80 \%$ of the section not recovered by coring operations. The activation volume, a sphere of about $1 \mathrm{~m}^{3}$ surrounding the tool, allows the recording of the accumulated bulk-rock chemical changes caused by hydrothermal exchange between the oceanic crust and circulating seawater. That is, the geochemical logs record the chemistry of the altered basalts plus secondary minerals filling the void spaces (fractures and pores) and provide an integrated measurement of the composition of the bulk crust.

Major elemental oxide weight percent abundances were calculated from geochemical logging measurements in Hole 504B (Fig. 3), as were concentrations of the elements S and Gd. U and Th concentrations in the basalts are so low that they are not displayed. Some discrepancies exist between the log-derived chemi$\mathrm{cal}$ analyses and those obtained from the core samples by X-ray fluorescence (XRF) (Fig. 3). For example, there is a general increase in the log-derived curve of $\mathrm{Mg}(+\mathrm{Na})$ upward in the hole, which is possibly the result of large amounts of $\mathrm{Mg}$ addition to the crust during interaction with seawater. The corresponding $\mathrm{Ca}$ decrease in the log-derived analyses is consistent with $\mathrm{Ca}-\mathrm{Mg}$ exchange observed during experimental seawaterbasalt reactions at elevated temperatures (Mottl et al., 1983). The observation is somewhat complicated, however, by the fact that $\mathrm{Mg}$ is always measured together with $\mathrm{Na}$ in the log-derived data because of the calculated scheme. Core analyses, in fact, show a slightly decreasing Mg content upward in the hole (Alt et al., 1986), which correlates with $\mathrm{Ti}$ and $\mathrm{Na}$ decreases and a $\mathrm{Ca}$ increase. Alt et al. (1986) interpreted this change to reflect slight changes in the compositions of the freshest basalts from the dikes compared to the pillows, even though the overall composition of basalts in the hole is remarkably uniform. There is also a problem with the $\mathrm{Ti}$ analyses (core values range from $0.7 \%$ to $1.1 \% \mathrm{TiO}_{2}$, whereas the log-derived analyses range from $0.7 \%$ at the top of the hole to $1.5 \%$ near the bottom, Fig. 3).

Some of these differences between the core and log analyses are attributed to the different nature of the analysis techniques (spot core samples of relatively fresh basalt vs. continuous, logderived measurements of bulk-rock chemistry). Also, either coring operations selectively sample only the least altered of the basalts in the section or, more likely, the recovered rocks reflect the appropriate composition of the basalts but do not properly represent the relative abundances of secondary minerals filling fracture and breccia zones.

\section{MINERALOGY MODEL OF HOLE 504B}

The elemental abundances from the geochemical logs can be inverted using a correlation matrix to determine the proportions of ideal minerals that might be present in the well (Hertzog et al., 1987). The average elemental compositions of selected minerals are input into the model. In the Hole 504B case, plagioclase $\left(\mathrm{An}_{70}\right)$, clinopyroxene, smectite, chlorite, calcite, and pyrite were used as the representative mineral suite. The mineral compositions were input as end members into an inversion matrix with the dry weight percent oxide compositions of $\mathrm{Si}, \mathrm{Al}$, $\mathrm{Fe}, \mathrm{Ca}, \mathrm{K}, \mathrm{Ti}, \mathrm{Na}+\mathrm{Mg}$, and $\mathrm{S}$ from the geochemical logs. Even though the elemental compositions may vary in their accuracies, the chemical differences between the different minerals observed in Hole 504B are so extreme that the derived mineralogy model should be useful.

The mineralogy model indicates two major mineralogical suites within the hole (Fig. 4). Plagioclase and clinopyroxene (i.e., fresh basalt) form the bulk of the formation. A second component appears as large "spikes" of (1) K-rich celadonites and zeolites in Layer 2A (modeled as K-rich smectites), (2) Mgrich clays such as smectite in the pillows of Layer $2 \mathrm{~B}$, and (3) Ferich chlorites in the dikes of Layer $2 \mathrm{C}$. K-rich celadonite and zeolites in Layer 2A have been artificially grouped into the smectites in the mineralogy model. That is, the "ideal" composition of smectite used in the model has considerable $\mathrm{K}$ (the celadonite component), even though smectites ordinarily have no $\mathrm{K}$ present within their structure. The mineralogy model indicates that the $\mathrm{Mg}$ increase and $\mathrm{Ca}$ decrease observed in the geochemical logs to occur from the dikes at the bottom of the hole to the pillows at the top of basement can be attributed to the transition from high-temperature chlorites that are abundant in the dikes to an abundance of $\mathrm{Mg}$-rich, Ca-poor smectites filling fracture zones and cementing breccias in the pillow sections of Layers $2 \mathrm{~A}$ and $2 \mathrm{~B}$ in Hole 504B. Indeed, just such a $\mathrm{Mg}$ sink and $\mathrm{Ca}$ source in the oceanic crust was predicted, based upon estimates of the few clay-filling fracture zones and breccias that were recovered within the $20 \%$ of section sampled by the coring procedure (Alt et al., 1986).

This change in mineral compositions and abundances may explain the permeability and porosity variations that indicate that the dikes are much tighter, lower permeability rocks than the pillows (Anderson et al., 1985b; Becker, this volume) (Fig. 4). Electrical resistivity measurements indicate that the apparent porosity of the formation drops from $15 \%$ to $0.3 \%$ from Layer $2 \mathrm{~A}$ to Layer 2C (Becker, 1985). However, flow- and pulse-test measurements using hydraulic packers demonstrate that the permeability, though high in the upper pillows of Layer $2 \mathrm{~A}$, is constant and low within the pillows of Layer 2B, even though the apparent porosity is high (Anderson et al., 1985a; Becker, this volume).

A pattern is evident in the abundances, as well as the previously described compositions, of minerals within Layer 2B that may explain why the apparent porosity is high yet the permeability remains low in these pillows (Fig. 4). Whereas extensive smectite and zeolite alteration products are present throughout Layer $2 \mathrm{~A}$, smectites are confined largely to fracture or breccia zones between individual eruption-event boundaries in Layer 2B (spikes in Fig. 4), and chlorites are found only along contacts between the largely unaltered basaltic dikes of Layer 2C (Alt et al., 1986).

This variation in the abundances of alteration products correlates with changes in the apparent porosity curve determined from the electrical resistivity log (Becker, Sakai, et al., 1988; Pezard and Anderson, this volume). Much void space exists in the Layer 2A pillow sequence, in spite of the extensive, low-temperature precipitation of celadonite and zeolite minerals (Anderson 


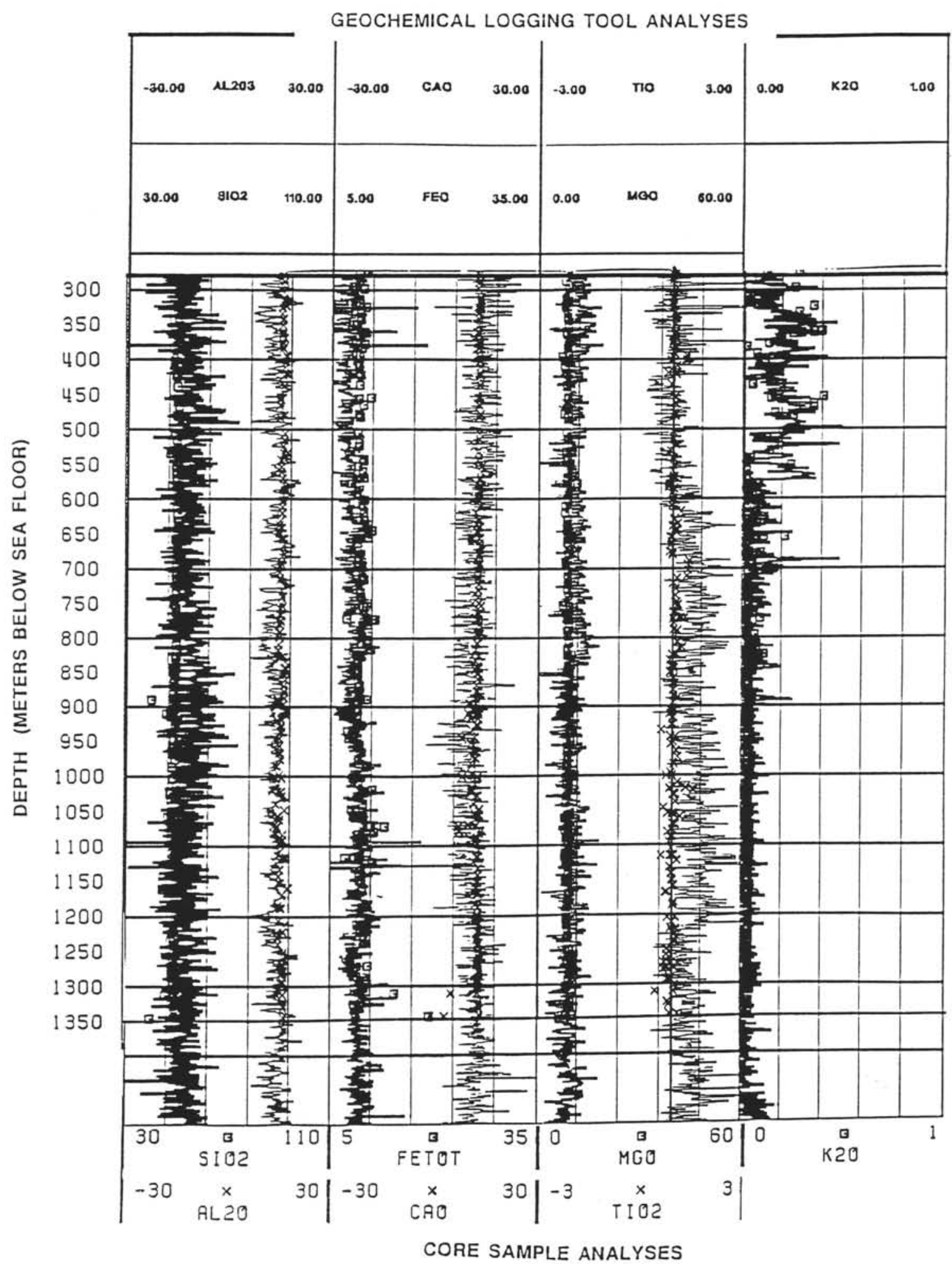

Figure 3. Dry weight percent oxide concentrations from geochemical logs in Hole 504B. Symbols are from core analyses by XRF. Depth given in meters below seafloor (subtract $3470 \mathrm{~m}$ to determine depth below seafloor).

and Zoback, 1983). Abundant fracture zones are present in the pillows of Layer 2B, but they are filled with smectite-cemented breccias and so are of relatively low permeability. The resistivity of these smectites is low relative to basalt and close to that of seawater (Pezard et al., 1988). Thus, the apparent porosity is caused not by seawater present in open fractures (as is usually assumed in porosity-permeability transforms), but by the high electrical conductivity of hydroxyl-bearing alteration minerals present within plugged fracture zones in Layer 2B (Becker, Sakai, et al., 1988; Pezard and Anderson, this volume). As such, the apparent porosity curve represents a fossil permeability profile within Layer $2 \mathrm{~B}$, and the fracture zones must have been 


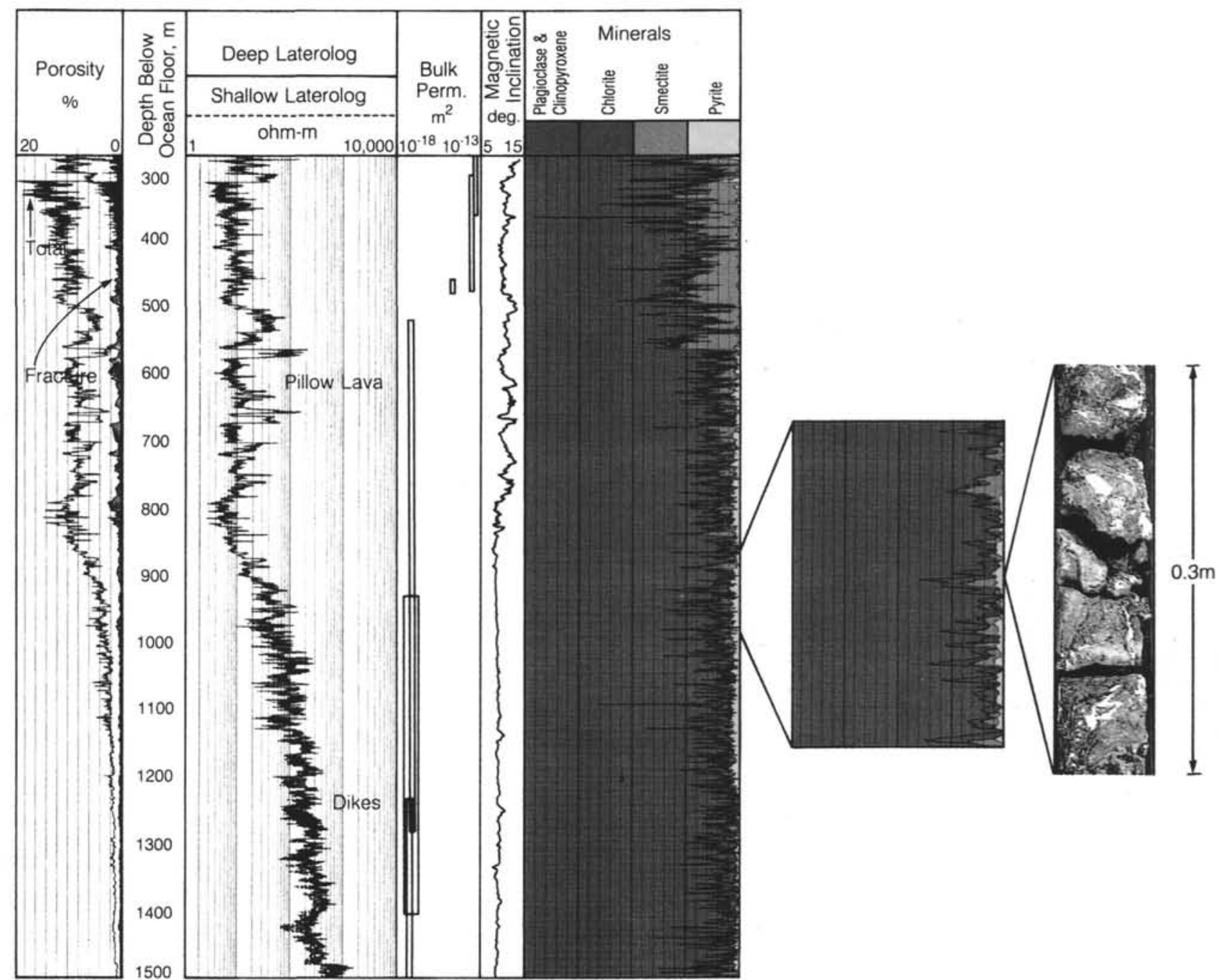

Figure 4. Geophysical and geochemical logs from Hole 504B. Total porosity and fracture porosity logs are derived from the dual laterolog (Pezard et al., 1988). The apparent, or false, porosity discussed in text is the difference between these two porosities. The bulk permeability measurements were made in Hole 504B by inflating packers against the wellbore and pumping pressure pulses (from Anderson et al., 1982, 1985b; Becker, this volume). The magnetic inclination is from the three-axis borehole magnetometer (Kinoshita et al., this volume). To the right of the mineralogy model derived from the geochemical logs is an enlargement of the stockwork mineralization zone. Finger-size crystals are evident in the accompanying core photograph of the stockwork located within the mineralogy model by the abundance of pyrite from the log and core. From Anderson et al. (1988b).

filled by the precipitation of secondary minerals during the aging of the hydrothermal circulation system at Hole 504B.

\section{INTEGRATED CHEMICAL FLUXES}

The crustal section at Hole 504B contains evidence of at least three different alteration events that dominate separate stratigraphic intervals: (1) seafloor weathering in Layer 2A; (2) lowtemperature, reducing alteration in Layer $2 \mathrm{~B}$; and (3) high-temperature, greenschist metamorphism in Layer 2C. Moreover, the rocks throughout the section record the effects of time-varying alteration processes, from seawater-dominated processes at the ridge axis to rock-dominated, off-axis hydrothermal circulation (Alt et al., 1986). In order to determine the total cation exchange between basalts and seawater that occurred during these different alteration processes, we must characterize the changes in elemental abundances between the freshest basalts found in the deepest dikes of Hole 504B and the shallower, more heavily altered rocks.
The elemental variations caused by alteration cannot be estimated simply by differencing the oxide weight percent in the altered rock from that in the protolith (the fresh, unaltered basalt). Either a constant-volume assumption must be made for the rock during alteration (a common assumption), or a constant mass must be assumed for an incompatible element such as $\mathrm{Gd}$ or $\mathrm{Ti}$ in the hole. The changes in the elements of interest can then be normalized to the concentrations in the rock at each depth vs. that in the protolith. We chose the former, even though on a small scale there clearly has been a volume change associated with the reactions that form the breccias in Hole 504B. Use of the constant-volume assumption will allow us to test our integrated flux calculations against the latter. That is, we will calculate fluxes for the incompatible elements, and their magnitudes will give us a good measure of how accurate our constant-volume assumption really is.

The methodology used to calculate the integrated chemical fluxes into and out of the oceanic crust in Hole 504B in the fol- 
lowing assumes that to the first order, no volume change occurs during the alteration process.

We begin by smoothing the log-derived, elemental oxide curves, each of which is then normalized to the average composition of the log values found at the base of the hole (Fig. 5). In most cases, these values correspond to the freshest basalts recovered by the coring operation (identified as the visibly least altered by Alt et al., 1985, and Sparks and Uhlig, this volume; see Fig. 5 for the assumed composition of the freshest basalt). The exception is $\mathrm{Ti}$, where a shift of $0.5 \%$ was required to bring the $\log$ vs. core analyses into agreement (see the preceding text). We recognize that any systematic errors between the log-derived elemental abundances and the true composition of the protolith will produce continuously increasing- or decreasing-with-depth (linear) integrated geochemical fluxes. The disadvantage of using the less accurate, log-derived elemental abundances is more than offset by the advantage that these geochemical logging tool measurements are continuous throughout the well.

It should be recognized that integrated flux calculations in drill holes where the primary igneous composition changes with depth must be properly zoned to account for the changes in the protolith before integrated fluxes can be calculated. Hole 504B is unusual because of the remarkable constancy of the composition of fresh basalts throughout the well.

\section{CHEMICAL EXCHANGE IN HOLE 504B}

To quantify the total chemical exchange that occurred in Hole 504B between the basalts and seawater, a correction must be made for the apparent volume changes that accompanied alteration (assuming a constant volume for Hole 504B). As noted previously, a significant percentage of the porosity of the well measured by electrical resistivity logs (Fig. 4) is, in fact, apparent porosity caused by the similarity between the electrical conductivity of alteration minerals that fill cracks and voids in the crust and that of true, water-filled porosity (Pezard and Anderson, this volume). This effect can be seen by considering the correlation of $\mathrm{Si}, \mathrm{Al}, \mathrm{Mg}$, and $\mathrm{Ca}$ fluxes with the apparent porosity (Fig. 6) in heavily altered Layer $2 \mathrm{~B}$. Si and $\mathrm{Mg}$ increase and $\mathrm{Al}$ and $\mathrm{Ca}$ decrease with increased apparent porosity, indicating that high porosity zones are actually filled with less dense, $\mathrm{Mg}$ - and Si-rich, Al- and Ca-poor clays (relative to fresh basalt).

This correlation between apparent porosity and compositional variations can be quantified by calculating correlation coefficients between major elements and porosity at each depth throughout the well (Fig. 7). The range of depths with significant correlation between the various elements and porosity extends from 3750 to $4400 \mathrm{~m}$ below rig floor (mbrf $=$ mbsf + $3470 \mathrm{~m}$ ), the interval of the well where porosities are highest. In the dikes, there is little correlation between major elements and porosity. Pezard and Anderson (this volume) describe more fully the causes and consequences of this "false" porosity (also shown in Fig. 4).

From Lesher et al. (1986, after Gresens, 1967), the total integrated mass flux $\left(F_{i}\right)$ of each element $(i)$ over the depth interval of the basement section of the well $\left(z_{1}\right.$ to $\left.z_{2}\right)$ is

$$
F_{i}=\rho_{\mathrm{b}} \int\left(X^{b}{ }_{i}-X^{a}{ }_{i}\right)\left[\left(1-\phi_{b}\right) /\left(1-\phi_{a}\right)\right] \mathrm{dz},
$$

where $X^{b}{ }_{i}$ is the weight fraction of element $i$ in the altered rock $b$, and $X^{a}{ }_{i}$ is that in the fresh basaltic protolith $a$. Dry-bulk density $\left(\rho_{b}\right)$ is measured by the geophysical logs and averages $2.4 \mathrm{~g} / \mathrm{cm}^{3}$ (Anderson et al., 1985). The constant-volume correction is estimated as the difference between the total porosity $\left(\phi_{b}\right)$ and the fracture porosity $\left(\phi_{a}\right)$ in the well (Fig. 4).
Alternatively, the assumed immobility of the incompatible elements Gd or Ti could be used to calculate an integrated elemental flux:

$$
F_{i}=\rho_{b} \int\left(X^{b}{ }_{i}-X^{a}{ }_{i}\right)\left(\mathrm{I}_{b} / \mathrm{I}_{a}\right) \mathrm{d} z .
$$

The results of the total flux calculation are similar using either equation (1) or (2). The absolute difference between the two assumptions (constant volume vs. immobile elements) can be seen by the apparent mobility of Gd calculated using the constantvolume assumption (Fig. 8). Use of $\mathrm{Ti}$ is complicated by the poor accuracy of the log-derived measurement (Fig. 9). The anomalous Gd flux can be taken as a measure of the degree of error in the constant-volume assumption in the Hole 504B calculation. This error, using log-derived analyses, is about $0.1 \%$ (Table 1), an accuracy similar to that in the Lesher et al. (1986) study using core-derived, laboratory analyses.

\section{IMPLICATIONS OF THE INTEGRATED CHEMICAL FLUX CALCULATIONS}

Assuming that our choice for the average composition of the protolith is indeed representative of the fresh basalt of Hole 504B, there have been significant total mass fluxes of $\mathrm{Si}, \mathrm{Ca}$, $\mathrm{Mg}$, and $\mathrm{Fe}$ and small changes in $\mathrm{Al}$ within Hole 504B (fluxes of the oxides are shown in Fig. 9 and total fluxes of the oxides and elements are given in Table 1).

The observed flux of $\mathrm{Si}$ into the crust, particularly from the bottom of the hole to 4300 mbrf (Fig. S), is corroborated by observations of the core where abundant quartz was found filling fractures (particularly from 4300 to $4500 \mathrm{mbrf}$ ). As discussed previously, the $\mathrm{Mg}$ increase and $\mathrm{Ca}$ decrease are probably caused by exchange of cations during chemical reactions between hot seawater and basalt (Bischoff and Seyfried, 1978; Mottl et al., 1978, 1979).

The Fe loss from the pillows of Layer $2 \mathrm{~B}$ may be due to reactions occurring during low-temperature, off-axis fluid circulation, such as those causing the Fe-rich hydrothermal deposits of the Galapagos (Bender, 1983) and Mariana mounds (Leinen et al., 1988). Alternatively, a relative increase in the Fe content of the dikes over fresh basaltic composition may have been caused by the addition of chlorite to the bulk-rock chemistry. In that case, the Fe flux in Figure 9 should be shifted to the right to indicate more enrichment in the dikes, rather than depletion in the pillows.

In contrast, the small changes in the $\mathrm{Al}$ flux may be due primarily to analytical error within the log-derived abundance of Al. While some $\mathrm{Al}$ can be leached from basalt by hydrothermal fluids, most is thought to be reprecipitated locally as clays (or epidote in the greenschist facies section of the hole).

To establish the validity of these mass flux calculations, a comparison of the compositions of more altered basaltic breccia and adjacent, fresh basalts from three core intervals in the Layer $2 \mathrm{C}$ dikes is shown in Table 2 . The fluxes indicated from the differences between the breccias and the fresh basalts generally show the same differences in composition as those calculated from the geochemical logs (Fig. 9). Specifically, increases in $\mathrm{Si}$ and $\mathrm{Mg}$ and decreases in $\mathrm{Ca}$ and $\mathrm{Al}$ were observed. An Fe increase in each breccia vs. that of the adjacent fresh basalt was also observed, which might again indicate that a gain of $\mathrm{Fe}$ in the dikes is more correct than a loss of Fe in the pillows (Fig. 9).

The clay minerals, chlorite, and other alteration products recovered in the cores provide evidence that abundant hydrothermal alteration occurred in Hole 504B. The geochemical logs locate the sites of elemental sources and sinks (e.g., the $\mathrm{Mg}$ sink in smectites found filling fractures in the lower pillows of Layer 


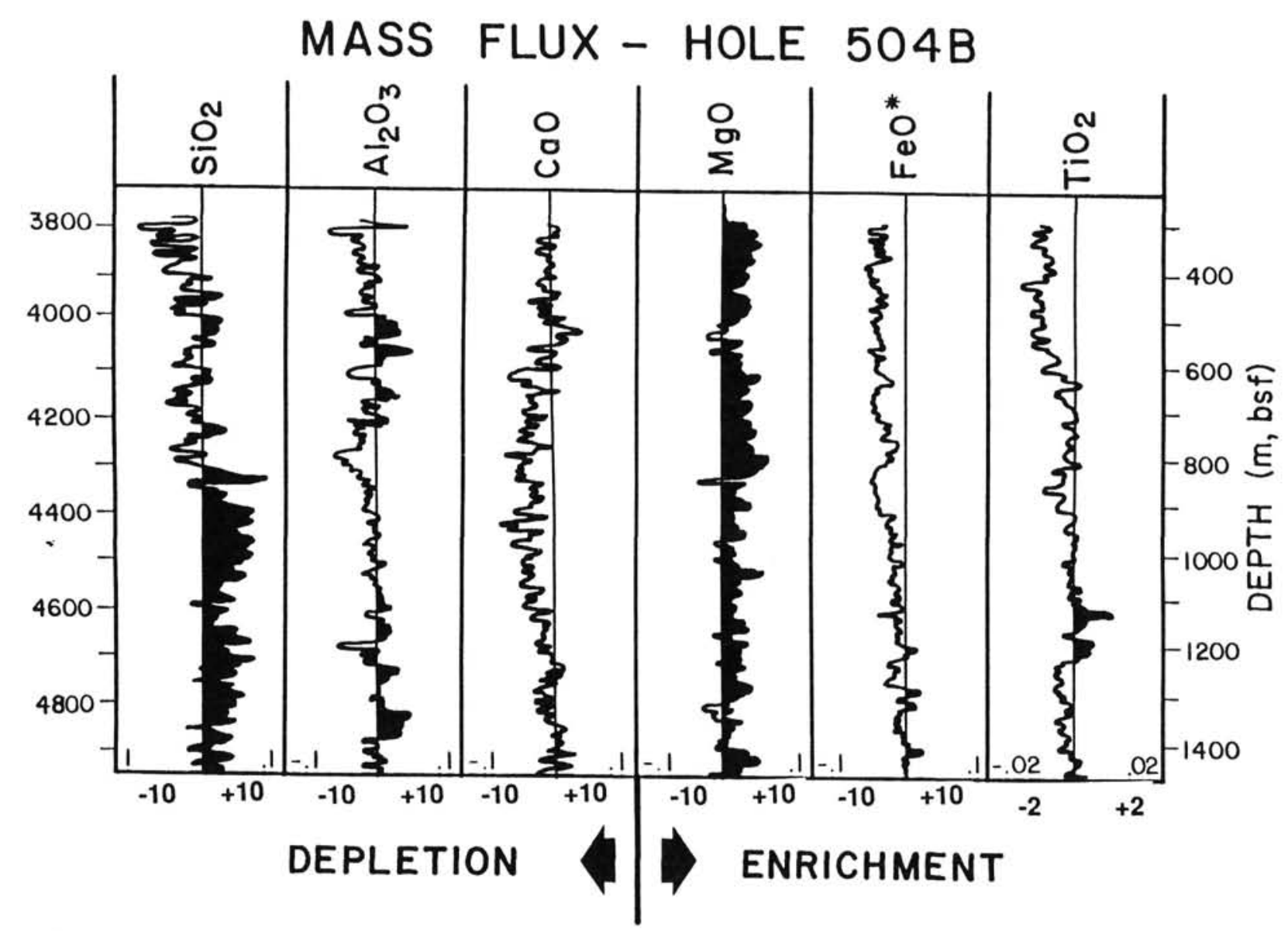

DEVIATION FROM FRESH BASALTIC COMPOSITION (in weight percent)
Mean and standard deviation
a feast-altered basalt and unaltered glass analyses from Hole 504B.

\begin{tabular}{ccc}
\multicolumn{2}{c}{ Basalt $^{\mathrm{a}}$} & \multicolumn{2}{c}{ Glass $^{\mathrm{b}}$} \\
\hline Mean 10 & Mean 10
\end{tabular}

$\begin{array}{lllll}\mathrm{SiO}_{2} & 50.06 & 0.45 & 50.66 & 0.66\end{array}$

$\begin{array}{lccrr}\mathrm{SiO}_{2} & 50.06 & 0.45 & 50.66 & 0.66 \\ \mathrm{TiO}_{2} & 0.94 & 0.09 & 0.97 & 0.07\end{array}$

$\begin{array}{ccccc}\mathrm{Al}_{2} \mathrm{O}_{3} & 15.43 & 0.59 & 14.96 & 0.64 \\ \mathrm{~F}_{2} \mathrm{O}_{3} & 2.98 & 0.59 & 1.65^{\mathrm{C}} & 0.07\end{array}$

$\begin{array}{lllll}\mathrm{Fe}_{2} \mathrm{O}_{3} & 2.98 & 0.59 & 1.65^{\mathrm{C}} & 0.07 \\ \mathrm{Fe} & 6.65 & 0.67 & 8.42^{\mathrm{c}} & 0.36\end{array}$

$\begin{array}{lllll}\mathrm{MnO} & 0.17 & 0.02 & 0.17^{\mathrm{d}} & 0.02 \\ \mathrm{MnO} & 0.46 & 0.38 & 8.20 & 0.34\end{array}$

$\begin{array}{llllll}\mathrm{MgO} & 8.44 & 0.38 & 8.20 & 0.34\end{array}$

$\begin{array}{llllll}\mathrm{CaO} & 12.94 & 0.43 & 12.78 & 0.24 \\ & & & \end{array}$

$\begin{array}{lllll}\mathrm{Na}_{2} \mathrm{O} & 2.19 & 0.30 & 2.00 & 0.15 \\ \mathrm{~K}_{2} \mathrm{O} & 0.02 & 0.01 & 0.03 & 0.01\end{array}$

$\begin{array}{lllll}\mathrm{P}_{2} \mathrm{O}_{5} & 0.07 & 0.01 & 0.08 & 0.01\end{array}$

$\begin{array}{lllll}\mathrm{CO}_{2} & 0.10 & .03 & 0.10^{\mathrm{d}} & 0.30\end{array}$

Total $\quad 99.99 \quad 100.02$

$\begin{array}{lllll}\mathrm{Fe}_{2} \mathrm{O}_{3}{ }^{\mathrm{T}} & 10.37 & 0.66 & 11.00 & 0.47\end{array}$

a Mean and standard deviation of 58 "least. altered" basalt analyses from the Leg 70 section of Hole $504 \mathrm{~B}$ (Hubberien et al., 1983). Least-altered analyses were selected based on $\mathrm{K}_{2} \mathrm{O}$ contents less than 0.10 wt.\% and recalculated water-free. Average does not include "and

ard deviation of 51 unal "eres $504 B$, ex (see text; Natland et al., 1983).

Assigned value of average least-altered ba.

salt from (a).

\section{FRESH \\ BASALTIC COMPOSITION}

(from Alt and Emmerman, 1985)

Figure 5. Smoothed curves of major element oxide concentrations (Fig. 3) normalized to the mean composition of the freshest basalt found in the dikes at the bottom of the hole (Alt et al., 1985, this volume). Shading is enrichment relative to the freshest basalt standard. Horizontal scale is in weight percent about average oxide abundance. 


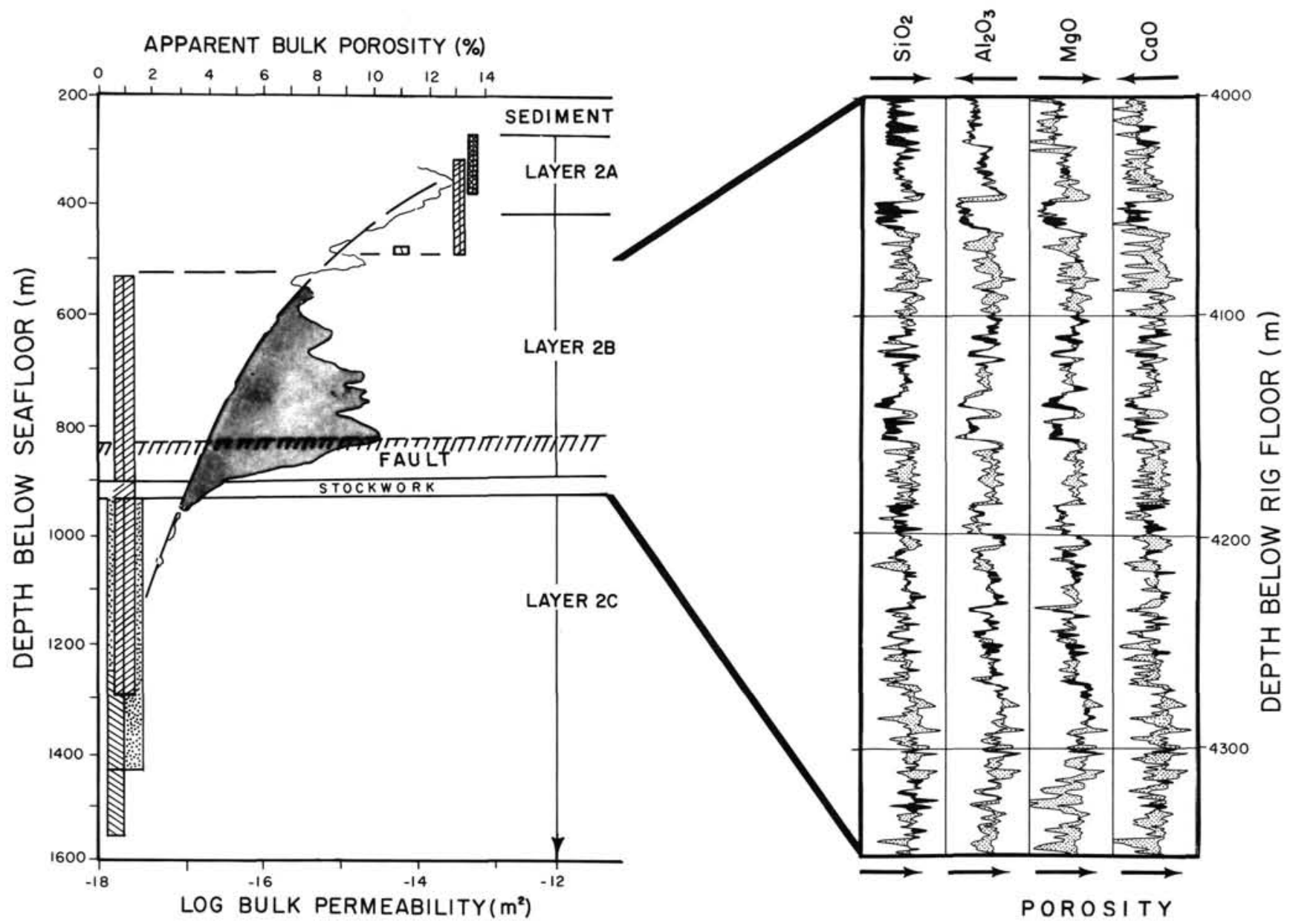

Figure 6. Apparent bulk porosity from an Archie's law interpretation of the dual laterolog measurements in Hole 504B (Pezard et al., 1988) and bulk-permeability measurements using packers to isolate the indicated intervals (from Anderson et al., 1985b; Becker, this volume) (see Fig. 4). The shaded zone is anomalously high in porosity but low in permeability (the false porosities discussed in the text) and is thought to contain extensive clay mineralization that plugs the plumbing system of the crust. The total porosity (including apparent, or false, porosity) increases to the right, and oxide abundances increase as shown by the arrows for the anomalous-porosity interval of Hole 504B. The horizontal scales are arbitrary, and the overlay of the curves with different units is only meant to show correlation.

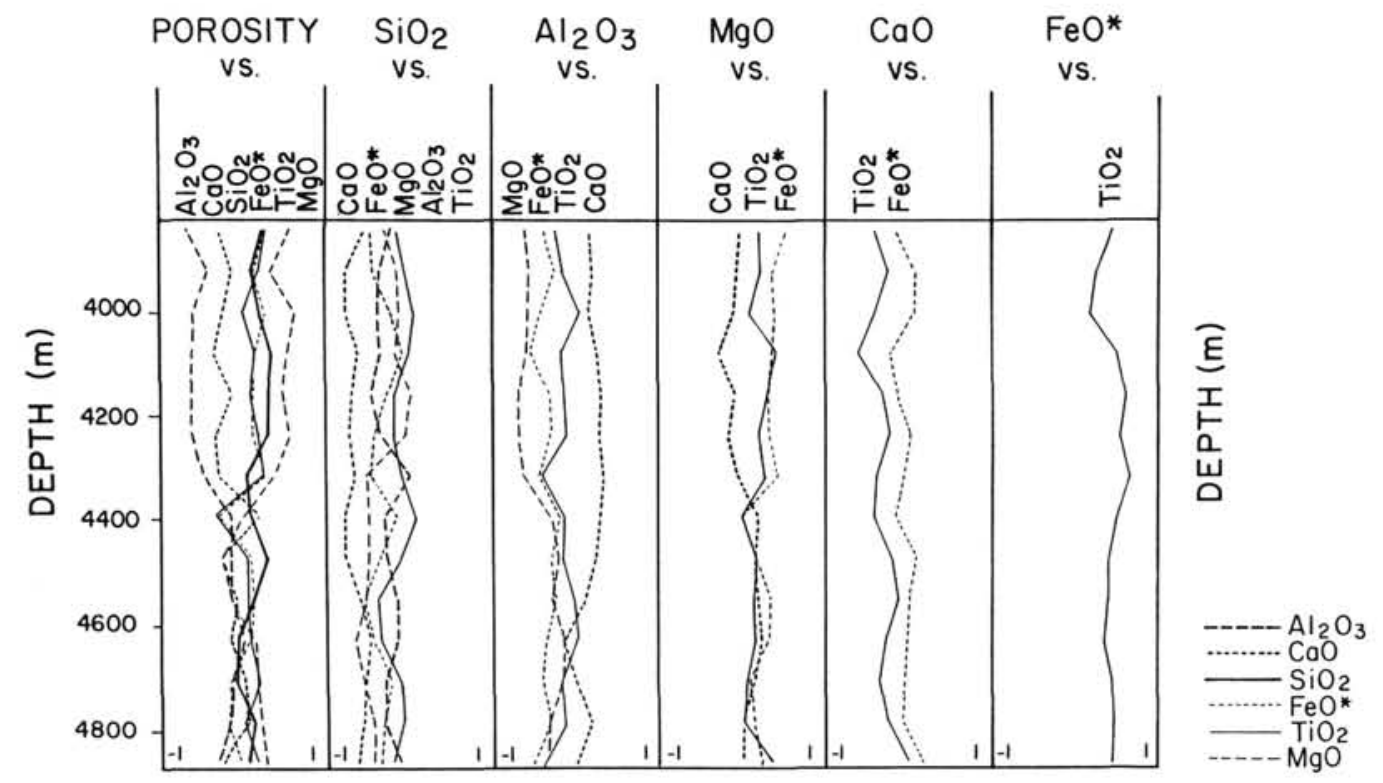

Figure 7. Correlation coefficients calculated at each depth point between the elemental abundance curves in Figure 3 and the total porosity (including apparent porosity) in Figure 6. 
"FALSE" POROSITY GADOLINIUM GADOLINIUM

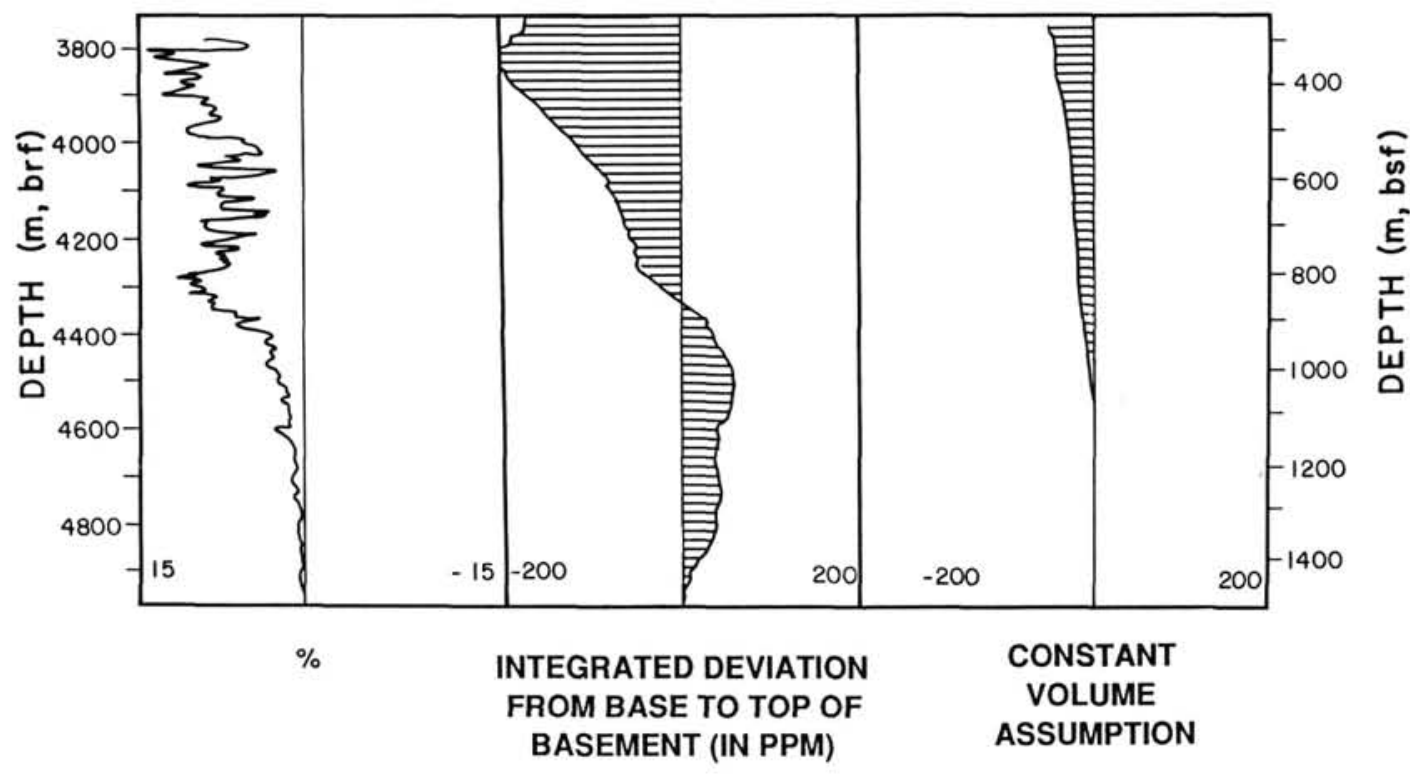

Figure 8. Comparison of the total apparent (false) porosity curve from Figure 6 with the Gd curve (in ppm) integrated over depth in Hole 504B, except that average basalt composition is taken as the log-derived Gd value at the very base of the hole, and the integrated mass flux ( $\left.F_{i}\right)$ for $\mathrm{Gd}$ (in ppm) as in equation (1) in the text. The volume changes from alteration of the oceanic crustal basalts account for most of the apparent increase in Gd content in the upper section of Hole 504B. An assumption of no HREE mobility during hydrothermal alteration leaves the curve at the right as a measure of the accuracy of the assumptions used to derive geochemical log-derived fluxes (particularly that of constant-volume before vs. after alteration of the basalts).

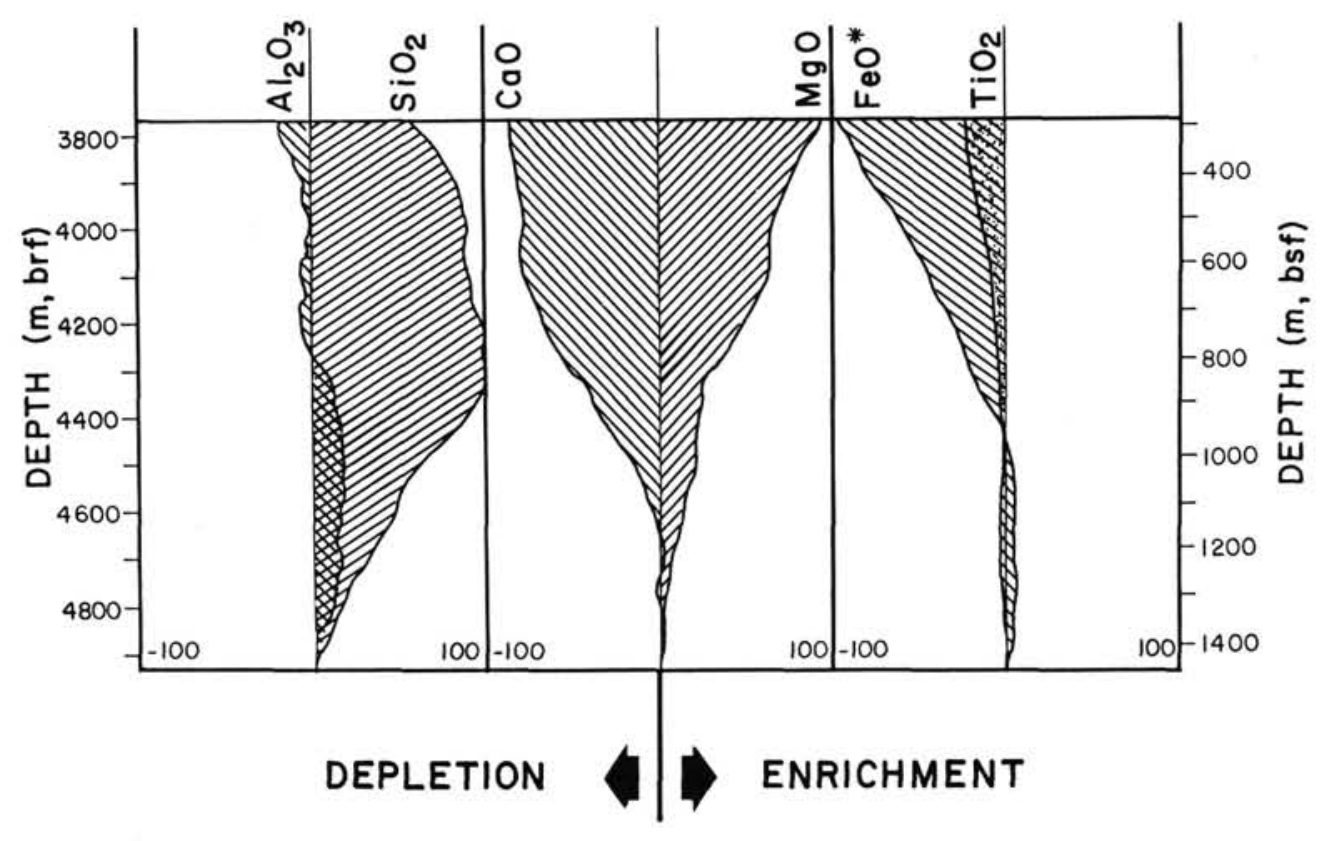

CONSTANT VOLUME ASSUMPTION

Figure 9. Integrated mass fluxes of the oxides for Hole 504B, from equation (1) in the text (see Table 1). 
Table 1. Geochemical mass flux, Hole 504B.

\begin{tabular}{|c|c|c|c|c|c|c|c|}
\hline \multirow[b]{2}{*}{ Element } & \multirow{2}{*}{$\begin{array}{c}\left(X^{b}{ }_{i}-X^{a}{ }_{i}\right) \mathrm{d} z \\
\text { (oxide percent } \\
\text { weight fraction } \\
\text { change) }\end{array}$} & \multirow{2}{*}{$\begin{array}{c}F_{i} \\
\text { (g elemental } \\
\text { flux change) }\end{array}$} & \multirow{2}{*}{$\begin{array}{c}F_{t} \\
\text { (g available } \\
\text { total of } \\
\text { element) }\end{array}$} & \multirow[b]{2}{*}{$\begin{array}{l}F_{i} / F_{t} \\
(\%)\end{array}$} & \multicolumn{2}{|c|}{$\begin{array}{l}\text { Change in composition } \\
(\mathrm{g} / 1200 \mathrm{~m} \text { column })\end{array}$} & \multirow[b]{2}{*}{$\begin{array}{l}\text { Water/rock } \\
\text { ratio }\end{array}$} \\
\hline & & & & & $\begin{array}{l}\text { Enrichment from } \\
\text { seawater }\end{array}$ & $\begin{array}{l}\text { Depletion from } \\
\text { black smoker }\end{array}$ & \\
\hline $\mathrm{Si}$ & +5650.0 & +76.5 & $81,250.0$ & +0.1 & 1.2 & & +63.0 in \\
\hline Al & -1650.0 & -25.5 & $28,786.0$ & -0.1 & & 0.04 & -638.0 out \\
\hline $\mathrm{Ca}$ & -8450.0 & -178.6 & $32,976.0$ & -0.5 & & 103.4 & -3.4 out \\
\hline $\mathrm{Mg}$ & +9350.0 & +164.3 & $17,919.0$ & +0.9 & 157.8 & & +1.04 in \\
\hline $\mathrm{Fe}$ & -9850.0 & -211.6 & $25,785.0$ & -0.8 & & 12.0 & -17.6 out \\
\hline \multirow[t]{2}{*}{ K } & $\mathrm{a}+500.0$ & $\mathrm{a}_{12.4}$ & 62.4 & $a+19.8$ & 47.2 & & +0.4 in \\
\hline & b -250.0 & 6.2 & & $b_{-9.9}$ & & 117.4 & -0.1 out \\
\hline $\mathrm{Ti}$ & -2120.0 & -27.0 & 1885.0 & -1.9 & - & - & - \\
\hline Gd & $c^{c}-4000.0$ & -0.0001 & 0.9 & -0.01 & - & - & - \\
\hline
\end{tabular}

${ }^{a}$ Layer $2 \mathrm{~B}$.

b Layer $2 \mathrm{C}$

${ }^{\mathrm{c}}$ In ppm.

Table 2. XRF elemental analyses: Hole 504B basalt and breccia.

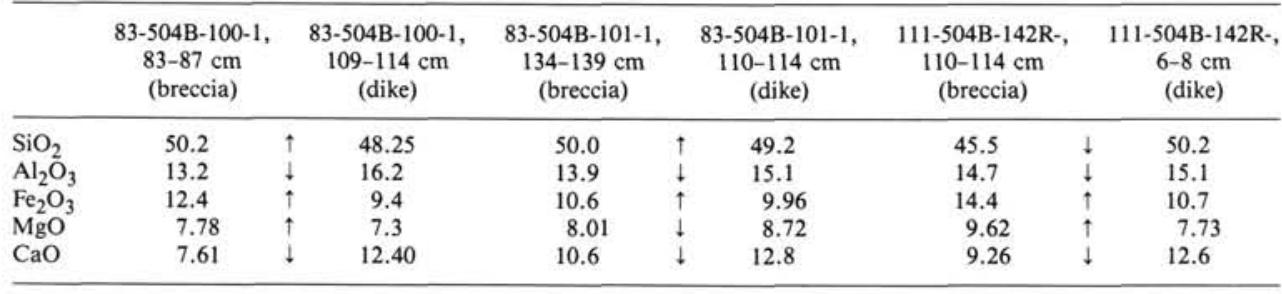

2B) and quantify the total chemical exchange caused by these reactions.

\section{TOTAL CHEMICAL FLUXES}

The integrals of the chemical fluxes for the basement section of Hole 504B were calculated by summing all depth intervals in Figure 9. For a column the height of the Hole 504B basement section, but only $1 \mathrm{~cm}^{2}$ in cross section, the total mass added to the oceanic crust during the alteration of basalts in Hole 504B was $76.5 \mathrm{~g}$ of $\mathrm{Si}$ and $164.3 \mathrm{~g}$ of $\mathrm{Mg}$ (Fig. 10 and Table 1). Correspondingly, $25.5 \mathrm{~g}$ of $\mathrm{Al}, 178.6 \mathrm{~g}$ of $\mathrm{Ca}$, and $211.6 \mathrm{~g}$ of $\mathrm{Fe}$ were lost to the ocean (Fig. 10).
The ratio of geochemical fluxes to total available elemental cations in fresh basalt $\left(F_{i} / F_{t}\right)$ suggests that insubstantial percentages of $\mathrm{Si}(+0.1 \%)$ and $\mathrm{Al}(-0.1 \%)$ were moved (Fig. 11 and Table 1). Although the Si flux appears large in absolute terms, it is not large in comparison to the amount of $\mathrm{Si}$ in fresh basalt. The $\mathrm{Si}$ increase was probably derived from reactions that occurred deeper in the crust because black smoker fluids contain significantly more $\mathrm{Si}$ than does seawater (see the following). Somewhat more $\mathrm{Mg}(+0.9 \%)$ gain than $\mathrm{Ca}(-0.5 \%)$ or $\mathrm{Fe}$ $(-0.8 \%)$ loss was observed. However, the large $\mathrm{K}$ flux becomes evident only when viewed in percentage terms (compare Figs. 10 and 11). It appears that almost $10 \%$ of the $\mathrm{K}$ is missing from

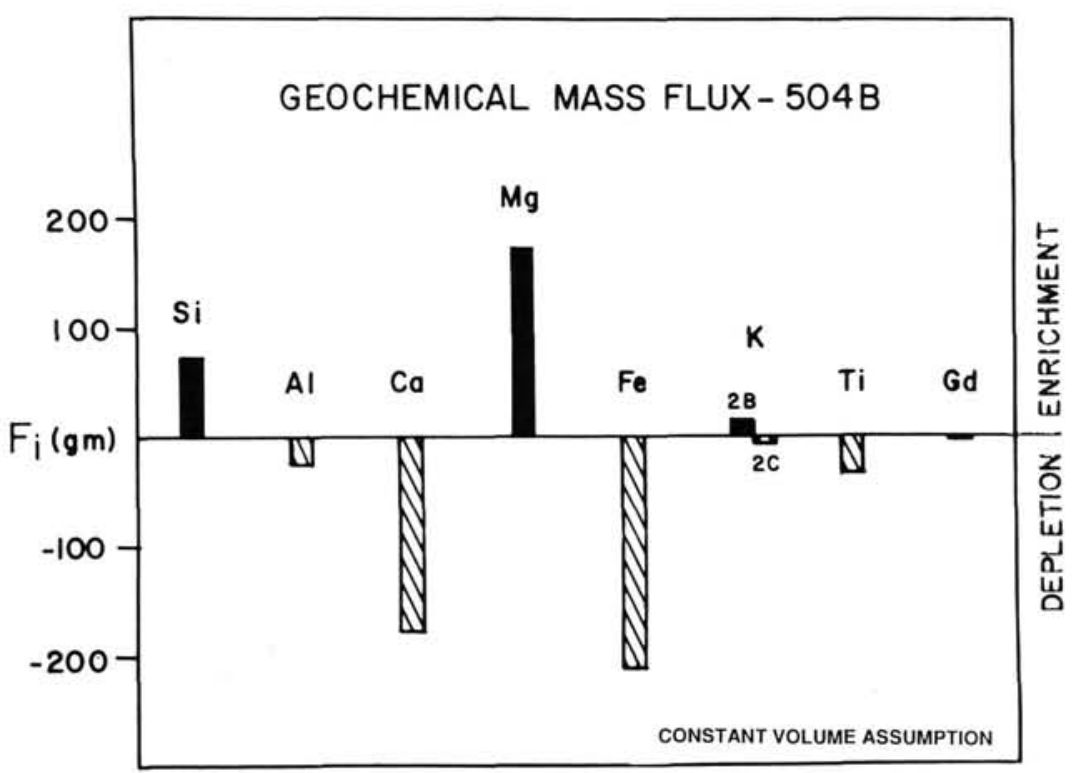

Figure 10. Total flux from the integrated mass flux for each element (Fig. 9 and Table 1). 


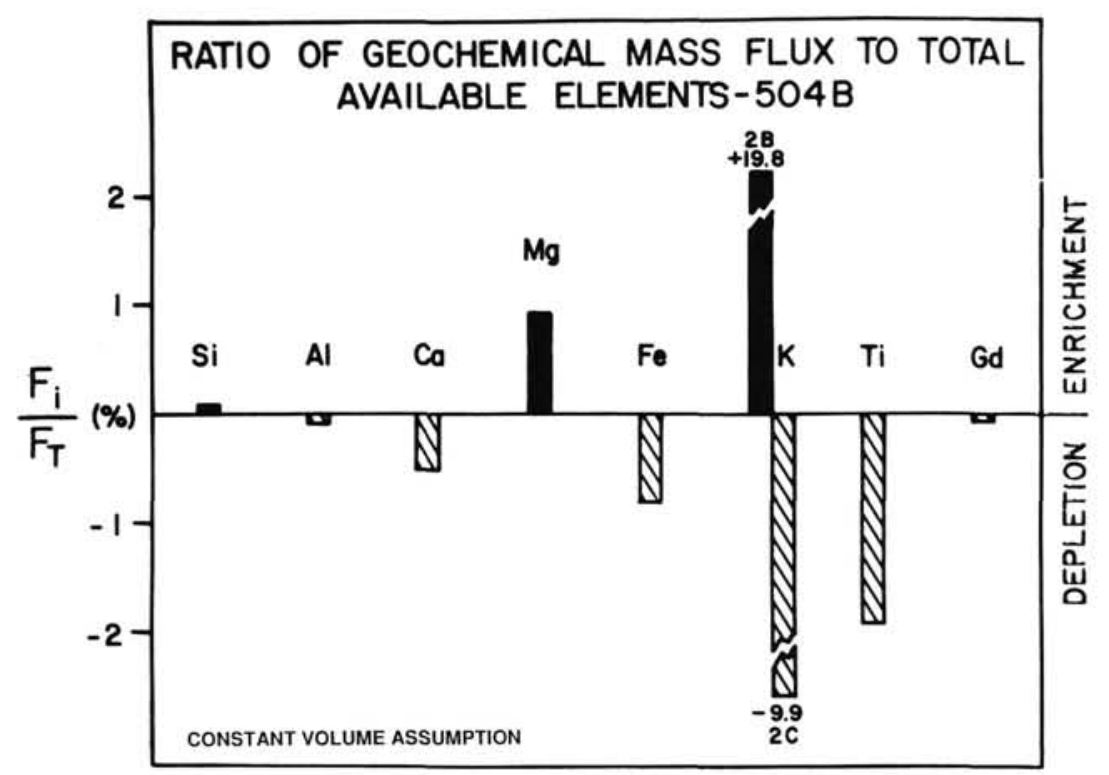

Figure 11. Ratio of integrated mass flux to the total of each element available in a $1-\mathrm{cm}^{2}$ column of fresh basalt extending the height of Hole 504B $\left(F_{i} / F_{t}\right.$, Table 1$)$.

Layer $2 \mathrm{C}$, whereas almost $20 \%$ more $\mathrm{K}$ (than that in fresh basalt) resides in Layers $2 \mathrm{~A}$ and $2 \mathrm{~B}$. The transfer of $\mathrm{K}$ from both Layer $2 \mathrm{C}$ (accounting for the loss of $\mathrm{K}$ there) and cold seawater is required to balance the increase observed in Layers $2 \mathrm{~A}$ and 2B.

\section{INTEGRATED WATER/ROCK RATIOS}

Water/rock ratios are frequently used by geochemists to quantify the amount of material that has reacted in hydrothermal systems (e.g., Mottl et al., 1983). The geophysical meaning of such water/rock ratios in the oceanic crust is problematic, however. Geophysical fluid-flow models describe the convection of water through a rock matrix in terms of velocity, permeability, and buoyancy forces. The water/rock ratio actually represents the reactivity of the fluid-rock system and, hence, is a function of flow rates vs. reaction rates.

To examine the possible implications of the log-derived, integrated chemical fluxes in Hole 504B, we have calculated water/ rock ratios in two ways. For the calculation of water/rock ratios of $\mathrm{Si}, \mathrm{K}$, and $\mathrm{Mg}$ into the crust, we have assumed all cations come from seawater of the composition given in Rosenbaum and Bischoff (1983) (Table 1). The calculated water/rock ratios are then the volumes of seawater required to completely exchange $\mathrm{Si}, \mathrm{K}$, or $\mathrm{Mg}$ cations with basalt to account for the total addition observed in the geochemical logging results of these elements to the crust.

For fluxes of $\mathrm{Al}, \mathrm{Ca}$, and $\mathrm{Fe}$ leaving the crust, we have assumed the extreme case that they exited as black smoker hydrothermal vent fluid. Again using compositions given in Rosenbaum and Bischoff (1983), we can calculate the water/rock ratio required to remove the missing cations in Hole 504B (Table 1). Here, we assume a beginning composition for the hydrothermal fluid of seawater, so that there are only two sources for the cations, seawater and the alteration of basalt. Water/rock ratios calculated in these ways might be considered minimal values because the effects of reaction kinetics are not considered. That is, all cations are assumed to be available for exchange with basalt. Offsetting this effect, however, is the fact that alteration of basalts is most likely the sum of several episodes of circulation and not simply the result of a single pass of water through the crust. In each such episode, the water/rock ratio is likely to be less than that calculated for a single-pass assumption.
Low water/rock ratios are found for $\mathrm{Ca}, \mathrm{Mg}, \mathrm{Fe}$, and $\mathrm{K}$ (Fig. 12). That is, reactions with only small volumes of hydrothermal fluid are required to account for the integrated mass fluxes of these elements observed in Hole 504B. These observations agree with the results from the basalt-seawater experiments of Mottl et al. (1983). A ridge axis, high-temperature origin for these fluxes is therefore likely. Of interest are the large water/rock ratios of $\mathrm{Si}$ and $\mathrm{Al}$ required to explain the log-derived fluxes in Hole 504B. Not enough $\mathrm{Al}$ is present in black smoker hydrothermal fluid to account for even the small mass missing from the Hole 504B basalts. Over 800 volumes of black smoker hydrothermal fluid must have exited the crust to remove the missing $\mathrm{Al}$. In this case, convection at $20 \mathrm{~cm} / \mathrm{yr}$ for the entire 5.9 Ma evolution of Hole 504B crust would be required to account for the missing $\mathrm{Al}$. In any event, the common practice of the normalization of basaltic compositions to $\mathrm{Al}$ content would not be wise in Hole 504B.

Water/rock ratios of $>80$ are required to account for the large increase in the $\mathrm{Si}$ flux thought to be caused by the precipitation of quartz at the Layer $2 \mathrm{~B} / 2 \mathrm{C}$ boundary. Although reactions with cold seawater circulating on the flanks of the ridge could have accounted for this $\mathrm{Si}$ deposition, the proximity of the quartz to the stockwork mineralization zone suggests that deposition occurred from a hot, hydrothermal fluid at the ridge axis. The cause of this anomalously high water/rock ratio for $\mathrm{Si}$ might then be that our assumption of a seawater source for the $\mathrm{Si}$ is incorrect. Instead, the $\mathrm{Si}$ could have come from a black smoker hydrothermal fluid that was rich in $\mathrm{Si}$, which was derived either from deeper in the crust than the base of Hole 504B or from laterally in the volcanic pile. A correspondingly lower water/rock ratio would then result. The deepening of Hole 504B that is planned for the next round of eastern Pacific drilling should shed further light on these uncertainties in the source of the Si flux.

As stated earlier, the water/rock ratio for Fe may be in error if precipitation of chlorites in Layer $2 \mathrm{C}$ has increased the $\mathrm{Fe}$ content of the dikes. Alternatively, the high water/rock ratio for Fe implies loss during cold, ridge flank deposition.

\section{SUMMARY}

Geochemical logs measure the bulk chemistry of Hole 504B crust at its current age of $5.9 \mathrm{Ma}$, and as such, they integrate the 


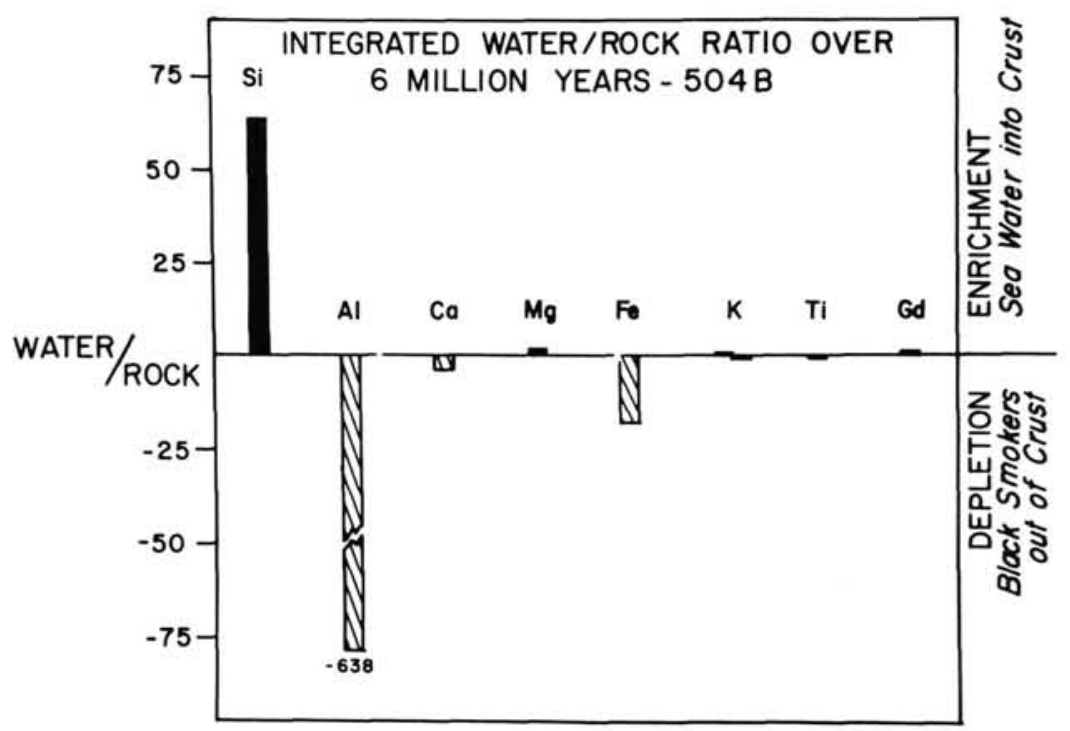

Figure 12. Integrated water/rock ratio over the last $5.9 \mathrm{Ma}$ in Hole 504B, calculated from the assumption that the source for cations going into the crust is from bottom seawater and the fluid output from the crust has the composition of black smoker hydrothermal vent fluid. Very large numbers for $\mathrm{Si}$ and $\mathrm{Al}$ mean that large volumes of fluid are required to enrich $\mathrm{Si}$ and deplete $\mathrm{Al}$ in the crust, because little is either leaving or entering, according to the assumption.

chemical effects of multiple, superimposed alteration processes. These new geochemical logging data, though significantly less accurate than laboratory chemical analyses, are extremely useful for two reasons: (1) the continuity of the data set allows for the quantification of elemental variations in all rock in a well, not just that recovered by core, and (2) the vertical extent of the data set allows for variations to be examined as a function of depth in the crust. The rapid accumulation of geochemical log-derived data for a wide variety of oceanic crustal drill holes will allow studies of the chemical mass fluxes between the oceanic crust and the oceans to be carried deeper and further back in time than possible from surface or core sampling alone.

\section{ACKNOWLEDGMENTS}

We wish to thank Captain Jon Marvel for invaluable assistance in the acquisition of the geochemical logging data at Hole 504B. Keir Becker and Hitoshi Sakai, co-chief scientists of ODP Leg 111, recognized the importance of the logging program and provided the time to do the experiments properly. Glen Foss, ODP operations manager, supervised the logging program and provided helpful assistance. We thank Carl Steefel of Yale for help with the methodology for calculating mass balances. This work was supported by the National Science Foundation through the Ocean Drilling Program.

\section{REFERENCES}

Alt, J. C., and Emmermann, R., 1985. Geochemistry of hydrothermally altered basalts: Deep Sea Drilling Project Hole 504B, Leg 83. In Anderson, R. N., Honnorez, J., Becker, K., et al., Init. Repts. DSDP, 83: Washington (U.S. Govt. Printing Office), 249-262.

Alt. J. C., Honnorez, J., Laverne, C., and Emmermann, R., 1986. Hydrothermal alteration of a $1 \mathrm{~km}$ section through the upper oceanic crust, DSDP Hole 504B: mineralogy, chemistry and evolution of basalt-sea water interactions. J. Geophys. Res., 91:309-335.

Alt. J. C., Laverne, C., and Muehlenbachs, K., 1985. Alteration of the upper ocean crust: mineralogy and processes in Deep Sea Drilling Project Hole 504B, Leg 83. In Anderson, R. N., Honnorez, J., Becker, K., et al., Init. Repts, DSDP, 83: Washington (U.S. Govt. Printing Office), 217-247.

Anderson, R. N., Delong, S. E., and Schwartz, W. M., 1980. Dehydration in the downgoing slab. J. Geol., 88:445-451.

Anderson, R. N., Dove, R., Broglia, C., Silver, L., James, E., and Chappell, B., 1988a. Elemental and mineralogical analyses from geochemical logs from the Cajon Pass scientific drillhole, and their preliminary comparison with core analyses. Geophys. Res. Lett., 29: 176-179.

Anderson,. R. N., Dove, R. E., and Pratson, E., 1989. The calibration of geochemical well logs in basalt, granite, and metamorphic rocks; and their use as a lithostratigraphic tool. Geol. Soc. London.

Anderson, R. N., and Hobart, M. A., 1976. The relation between heat flow, sediment thickness and age in the eastern Pacific. J. Geophys. Res., 81:1968-1989.

Anderson, R. N., Jarrard, R., Dove, R., Pezard, P., and Williams, C., 1988b. Logging for science. Schulmberger Tech. Rev., 38:4-12.

Anderson, R. N., Langseth, M. G., and Sclater, J. G., 1977. The mechanisms of heat transfer through the floor of the Indian Ocean. $J$. Geophys. Res., 82:3391-3409.

Anderson, R. N., O'Malley, H., and Newmark, R. L., 1985a. Use of geophysical logs for quantitative determination of fracturing, alteration, and lithostratigraphy in the upper oceanic crust, Deep Sea Drilling Project, Holes 504B and 558. In Anderson, R. N., Honnorez, J. Becker, K., et al., Init. Repts. DSDP. 83: Washington (U.S. Govt. Printing Office), 443-478.

Anderson, R. N., and Zoback, M. D., 1983. The implications of fracture and void distribution from borehole televiewer imagery in DSDP Holes 501 and 504B. In Cann, J. R., Langseth, M. G., Honnorez, J., Von Herzen, R. P., White, S. M., et al., Init. Repts. DSDP, 69: Washington (U.S. Govt. Printing Office), 225-270.

Anderson, R. N., Zoback, M. D., Hickman, S. H. and Newmark, R. L., 1985b. Permeability versus depth in the upper oceanic crust: in situ measurements, in Deep Sea Drilling Project Hole 504B, eastern equatorial Pacific. J. Geophys. Res., 90:3859-3889.

Ballard, R. D., and Francheteau, J., 1983. Geological processes of the mid-ocean ridge and their relationship to sulfide deposition. In Rona, P. A., Grassley, F. W., and Smith, S. M. (Eds.), Hydrothermal Processes at Sea Floor Spreading Centers: New York (Plenum), 17-27.

Becker, K., 1985. Large-scale electrical resistivity and bulk porosity of the oceanic crust, DSDP Hole 504B, Costa Rica Rift. In Anderson, R. N., Honnorez, J., Becker, K., et al., Init. Repts. DSDP, 83: Washington (U.S. Govt. Printing Office), 419-427.

Becker, K., Sakai, H., et al., 1988. Proc. ODP, Init. Repts., 111: College Station, TX (Ocean Drilling Program).

Bender, M., 1983. Pore-water chemistry, Sites 506-509, Deep Sea Drilling Project. In Honnorez, J., Von Herzen, R. P., et al., Init. Repts. DSDP, 70: Washington (U.S. Govt. Printing Office), 343-353. 
Bischoff, J. L., and Seyfreid, W. E., 1978. Hydrothermal chemistry of sea water from 25 to $250^{\circ} \mathrm{C}$. Am. J. Sci., 278:838-880.

Bowers, T., and Edmond, J. M., in press. Chemistry of hydrothermal fluids from the black smokers of the eastern Pacific. J. Geophys. Res.

Edmond, J. M., et al., 1979. Ridge crest hydrothermal activity and the balances of the major and minor elements in the ocean. Earth Planet. Sci. Lett., 48:1-18.

Gresens, R. L., 1967. Composition-volume relationships of metasomatism. Chem. Geol., 2:47-85.

Hekenian, R., Renard, V., and Cheminee, H., 1983. Hydrothermal deposits on the East Pacific Rise near $13^{\circ} \mathrm{N}$ : geological setting and distribution of active sulfide chimneys. In Rona, P. A., Grassley, F. W., and Smith, S. M. (Eds.), Hydrothermal Processes at Sea Floor Spreading Centers: New York (Plenum), 17 27.

Hertzog, R., Colson, L., Seeman, B., O'Brien, M., Scott, H., McKeon, D., Wraight, P., Grau, J., Schweitzer, J., and Herron, M., 1987. Geochemical Logging with Spectrometry Tools: Soc. Petrol. Engr. Pap., 18,792.

Hobart, M. A., Langseth, M. G., and Anderson, R. N., 1985. A geothermal and geophysical survey on the south flank of the Costa Rica Rift: Sites 504 and 505. In Anderson, R. N., Honnorez, J., Becker, K., et al., Init. Repts. DSDP, 83: Washington (U.S. Govt. Printing Office), 379-404.

Honnorez, J., Alt, J. C., Honnorez-Guerstein, B.-M., Laverne, C., Muehlenbachs, K., Ruiz, J., and Saltzman, E., 1985. Stockworklike sulfide mineralization in young oceanic crust: Deep Sea Drilling Project Hole 504B. In Anderson, R. N., Honnorez, J., Becker, K., et al., Init. Repts. DSDP, 83: Washington (U.S. Govt. Printing Office), 283-278.

Lesher, C. M., Gibson, H. L., and Campbell, I. H., 1986. Composition-volume changes during hydrothermal alteration of andesite at Buttercup Hill, Noranda District, Quebec. Geochim. Cosmochim. Acta., 50:2893-2705.

Leinen, M., McDuff, R., Delaney, J., Becker, K., and Schulteiss, P., 1988. Off-axis hydrothermal activity in the Mariana Mounds Field. EOS, Trans. Am. Geophys. Union, 88:1531.

Lupton, J. E., and Craig, H., 1983. Excess Helium-3 in the ocean above the East Pacific Rise. In Emiliani, C. (Ed.), The Sea (vol. 7): New York (Wiley), 279-284.

McDuff, R. E., and Edmond, J. M., 1982. On the fate of sulfate during hydrothermal circulation at mid-ocean ridges. Earth Planet. Sci. Lett., 57:117-132.

Morton, J. P., and Sleep, N., 1983. Hydrothermal circulation at midocean ridges. In Rona, P. A., Grassley, F. W., and Smith, S. M. (Eds.), Hydrothermal Processes at Sea Floor Spreading Centers: New York (Plenum), 9-17.

Mottl, M. J., Holland, H. D., and Corr, R. F., 1978. Chemical exchange during hydrothermal alteration of basalt by sea water I. Geochim. Cosmochim. Acta., 42:1103-1115.
1979. Chemical exchange during hydrothermal alteration of basalt by sea water II. Geochim. Cosmochim. Acta., 43:889-884.

Mottl, M. J., Druffel, E.R.M., Hart, S. R., Lawrence, J. R., and Saltzman, E. S., 1985. Chemistry of hot waters sampled from basement at Hole 504B. In Anderson, R. N. Honnorez, J., Becker, K., et al., Init. Repts. DSDP, 83: Washington (U.S. Govt. Printing Office), 479-510.

Mottl, M. J., Lawrence, J., and Keigwin, L., 1983. Elemental and stable-isotope composition of pore waters and carbonate sediments from DSDP Sites 501-504 and 505. In Cann, J. R., Langseth, M. G., Honnorez, J., Von Herzen, R. P., White, S. M., et al., Init. Repts. $D S D P, 69$ : Washington (U.S. Govt. Printing Office), 481-473.

Natland, J. H., Adamson, A. C., Laverne, Melson, W. G., and O'Hearn, T., 1983. A compositionally nearly steady-state magma chamber at the Costa Rica Rift: evidence from basalt glass and mineral data, Deep Sea Drilling Project Sites 501, 504, and 505. In Cann, J. R., Langseth, M. G., Honnorez, J., Von Herzen, R. P., White, S. M., et al., Init. Repts. DSDP, 69: Washington (U.S. Govt. Printing Office), 811-858.

Newmark, R. L., Anderson, R. N., Moos, D., and Zoback, M. D., 1985. Sonic and ultrasonic logging of Hole 504B and its implications for the structure, porosity, and stress regime of the upper $1 \mathrm{~km}$ of the ocean crust. In Anderson, R. N., Honnorez, J., Becker K., et al., Init. Repts. DSDP, 83: Washington (U.S. Govt. Printing Office), 479-510.

Pezard, P. A., Anderson, R. N., Howard, J., and Luthi, S. M., 1988. Fracture distribution and basement structure from the measurement of electrical resistivity in the Cajon Pass scientific drillhole, California. Geophys. Res. Lett., 15:1021-1024.

Rosenbaum, R. J., and Bischoff, J. L., 1983. Uptake and transport of heavy metals by heated sea water: a summary of the experimental results. In Rona, P. A., Grassley, F. W., and Smith, S. M. (Eds.), $H y$ drothermal Processes at Sea Floor Spreading Centers: New York (Plenum), 177-198.

Sleep, N. H., and Wolery, T. J., 1978. Thermal and chemical constraints on venting of hydrothermal fluids at mid-ocean ridge. J. Geophys. Res., 83:5913-5922.

Thompson, G., 1983. Basalt-sea water interaction. In Rona, P. A., Grassley, F. W., and Smith, S. M. (Eds.), Hydrothermal Processes at Sea Floor Spreading Centers: New York (Plenum), 225-278.

Von Damm, K. L., Grant, B., and Edmond, J. M., 1983. Preliminary report on the chemistry of hydrothermal solutions at 21 degrees north, East Pacific Rise. In Rona, P. A., Grassley, F. W., and Smith, S. M. (Eds.), Hydrothermal Processes at Sea Floor Spreading Centers: New York (Plenum), 369-390.

Date of initial receipt: 17 July 1988

Date of acceptance: 1 March 1989

Ms 111B-138 